\title{
Automatic measurement of water uptake and weeping sap excretion by root system
}

\author{
J. CZERSKI \\ Institute of Botany, Warsaw University, Warsaw \\ (Received: March 29, 1976)
}

\begin{abstract}
An apparatus is described which allows continuous recording of water uptake by a plant. The elements of this apparatus serve at the same time for measurement of root pressure. The size of the recorded portion of uptaken water and of weeping sap excreted by the plant root can be regulated.
\end{abstract}

\section{INTRODUCTION}

Investigation of the process of water uptake meets with many methodical obstacles resulting from the difficulty in ensuring optimal physiological conditions to the root system. The potometric method and its numerous modifications do not for instance provide for a normal gas exchange in the roots.

The sensitivity of the measuring apparatus to temperature variations, the limited size of the plants to be examined and the lack of automatic recording greatly hamper studies.

A review of numerous methods of water uptake measurement is given by Slavik (1974) and the many publications dealing with this subject prove that a search for more refined solutions is continued.

Neither is the here presented method of measurement of water uptake by plants free of all the above mentioned shortcomings. It is believed, however, that within a certain scope of these investigations it may be useful. Its advantage, distinguishing it from other methods, is the possibility of its application to measurements of root pressure as well. 


\section{APPARATUS FOR MEASUREMENT OF WATER UPTAKE}

The measurement principle is based on recording of water drops flowing from an injection needle under the action of the suction forces of a transpiring plant. A scheme of the set-up is shown in Fig. 1a. In vessel (1) of $100 \mathrm{~cm}^{3}$ capacity filled with water or nutrient medium the root system of plant (3) is enclosed by means of a rubber stopper (2). A glass tube (4) passes through the stopper reaching to the bottom of the vessel. The upper part of this tube is connected to a three-way cock (7) and a sensing device (9) by a rubber tube. The water taken up by the plant from vessel (1) causes in the closed system an underpressure, owing to which water starts dropping from the injection needle (13) and the internal pressure of the system becomes equal to atmospheric pressure. Water flows to the injection needle through glass tube (10) connec-

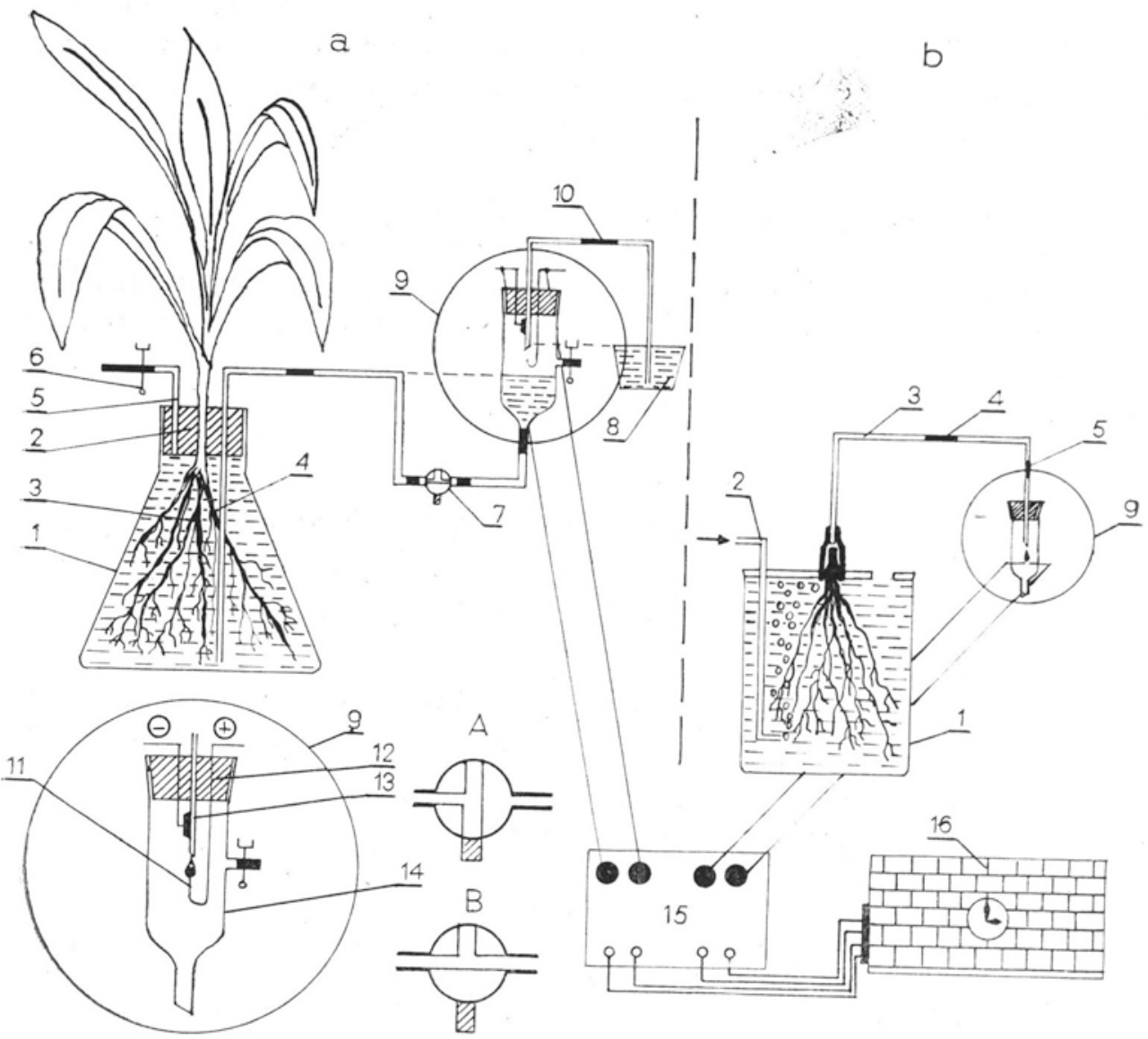

Fig. 1a, b. Apparatus for continuous measurement of water uptake by plants (a), and apparatus for continuous measurement of weeping sap exoretion by roots (b). Operation of apparatus described in text 
ted to an open reservoir (8). On the prolongation of the injection needle (13), which at the same time serves as electrode, a second electrode (11) is placed, made of thin chromo-nickel wire. The water drop at the moment of detachment from the injection needle connects both electrodes and then the momentary electric current from the supply system (15) dials the successive number in the counter (16). (The supply system and counters are described in an earlier paper - Czerski, 1972.) The programming clock switches on after one hour the next counter. Water uptake intensity is read as the number of pulses recorded by the particular counters.

The water in vessel (1) can be exchanged as follows: the three-way cock (7) is set in position A and the clip (6) closing glass tube (5) is opened. Light water suction through the free pass of tap (7) causes outflow of the fluid from vessel (1).

Refilling of vessel (1) with water or nutrient solution is done in the same way. After closing tube (5) and setting the three-way cock (7) in position $\mathrm{B}$, the water taken up by the plant produces a fall of the external pressure which is equalized with atmospheric pressure by outflow of drops from the injection needle.

Calibration of the system for water uptake measurement

The size of the recorded water drop flowing out of the injection needle was determined in terms of weight. The results of calibration are shown in Table 1. The recorded water portion taken up can be regulated by the diameter of the injection needle.

Table 1

Weight of water and sap drops recorded by apparatus

\begin{tabular}{|c|c|c|}
\hline $\begin{array}{c}\text { Diameter } \\
\text { of injection needle } \\
\text { mm }\end{array}$ & $\begin{array}{c}\text { Weight of outflowing } \\
\text { water drop } \\
\text { mg }\end{array}$ & $\begin{array}{c}\text { Weight of outflowing } \\
\text { weeping sap drop } \\
\text { mg }\end{array}$ \\
\hline 0.55 & $7.23 \pm 0.031$ & $8.75 \pm 0.013$ \\
0.65 & $10.23 \pm 0.0023$ & $10.90 \pm 0.015$ \\
0.80 & $12.44 \pm 0.0033$ & $13.02 \pm 0.48$ \\
0.90 & $13.90 \pm 0.0060$ & - \\
\hline
\end{tabular}

Experimental test of the method

Control measurements were performed on maize (Zea mays L. cv. Złota Karłowa) plants. They were reared in a phytotron chamber under conditions of $16-\mathrm{h}$ photoperiod and light intensity at the level of the

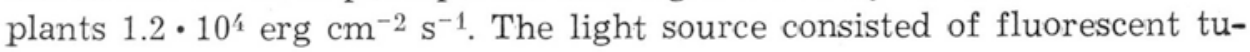


bes, 40W "Dzienne" and "Flora" (1:1). The plants were germinated on moist filter paper and transferred to vessels of $1.5 \mathrm{l}$. capacity containing mineral medium No. 20 described by B e n t le y (1959).

Determination of water uptake was done simultaneously on 3 maize plants aged 30 days in a 4-cycle light and darkness period. Periods of 6 - $\mathrm{h}$ light and $6 \mathrm{~h}$ darkness were applied alternatively. During the whole experiment air temperature was maintained at $22^{\circ} \mathrm{C} \pm 1^{\circ}$ and relative. air moisture at $70 \pm 5$ per cent.

The water uptake curves are shown in Fig. 2. They have characteristic

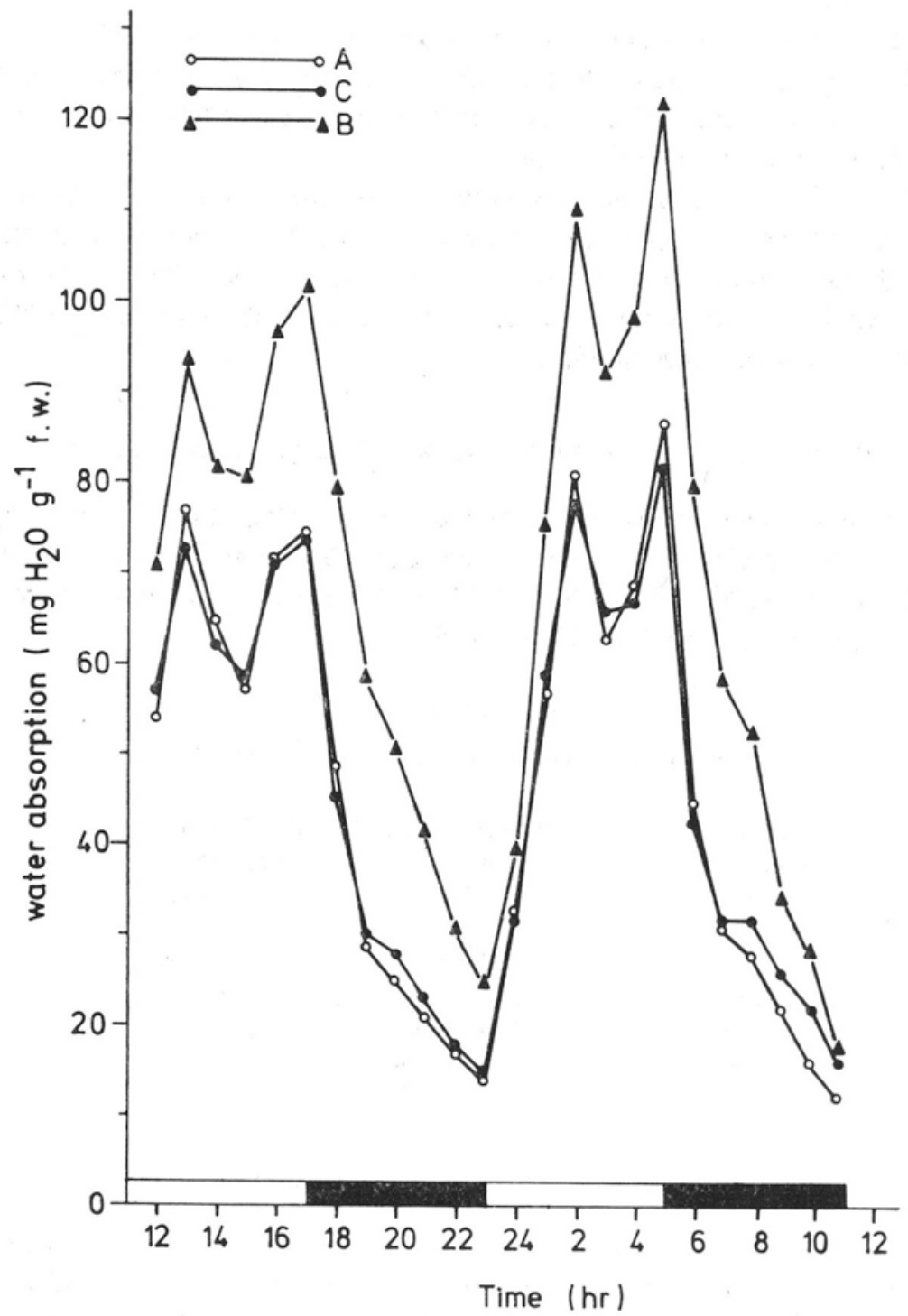

Fig. 2. Water uptake by 3 maize plants (A, B, C) in 6-hour cycles of light and. darkness 
courses for the light and darkness periods. In three of the plants changes in water uptake were found to be simultaneous with the change in light conditions. During the period of exposure to light, with only slight differences in temperature and air moisture, after several hours a distinct periodical decrease of the water uptake rate was noted. This phenomenon was observed repeatedly. Elucidation of the mechanism of changes in this rate will be possible in further investigations.

The results of measurement of the water uptake rate in the successive cycles of light and darkness are shown in Table 2.

Table 2

Weight of water uptaken by maize plant in 6-hour cycles of light and darkness $\left(\mathrm{g} \mathrm{H}_{2} \mathrm{O}\right.$ per plant)

\begin{tabular}{|l|c|c|c|c|c|c|}
\hline $\begin{array}{c}\text { Weight of } \\
\text { plant }\end{array}$ & $\begin{array}{c}\text { I } \\
\text { cycle } \\
\text { light }\end{array}$ & $\begin{array}{c}\text { I } \\
\text { cycle } \\
\text { darkness }\end{array}$ & $\begin{array}{c}\text { II } \\
\text { cycle } \\
\text { light }\end{array}$ & $\begin{array}{c}\text { II } \\
\text { cycle } \\
\text { darkness }\end{array}$ & $\begin{array}{c}\text { Amount of water } \\
\text { taken up in } \\
\text { 24 h }\end{array}$ & $\begin{array}{c}\text { Weight of water } \\
\text { per 1 g fr. wt. } \\
\text { g }\end{array}$ \\
\hline A 45.24 & 17.829 & 7.308 & 17.410 & 7.805 & 50.353 & 1.1 \\
B 22.42 & 11.761 & 6.490 & 12.185 & 6.272 & 36.710 & 1.6 \\
C 30.61 & 12.168 & 4.751 & 11.950 & 4.835 & 33.704 & 1.1 \\
\hline
\end{tabular}

The quotient of water uptake by fresh plant weight calculated for $24 \mathrm{~h}$ is the same for plants $\mathrm{A}$ and $\mathrm{C}$ amounting to 1.1 , whereas for plant $\mathrm{B}$ it is somewhat higher - 1.6. Water uptake in light was in the plants tested about two times higher than in darkness.

The agreement of results obtained in the successive cycles of light and darkness is evidence of the correct recording of water uptake.

An indispensable condition for obtaining accurate results is in the first place maintenance of constant ambient temperature. Although the measurements are performed in a thermostated atmosphere the transition from one cycle to the other, e.g. from light to darkness causes periodical thermic changes. Their influence may be excluded by placing the measuring set-up in a thermostated water reservoir of high thermic capacity or by taking into account the correction read from the control system.

\section{Control system}

The control set-up consists of the same elements as the experimental system. Fig. 3 shows the scheme of the set-up with water and gas phase capacity equal to that of the experimental system.

In dependence on the setting of cocks (1) and (2) changes in volume caused by a rise or fall of temperature can be recorded. When cock (2) is closed and (1) opened, the increasing volume of the fluid in vessel (3) and air in the sensing device (4) causes water to drop through glass 


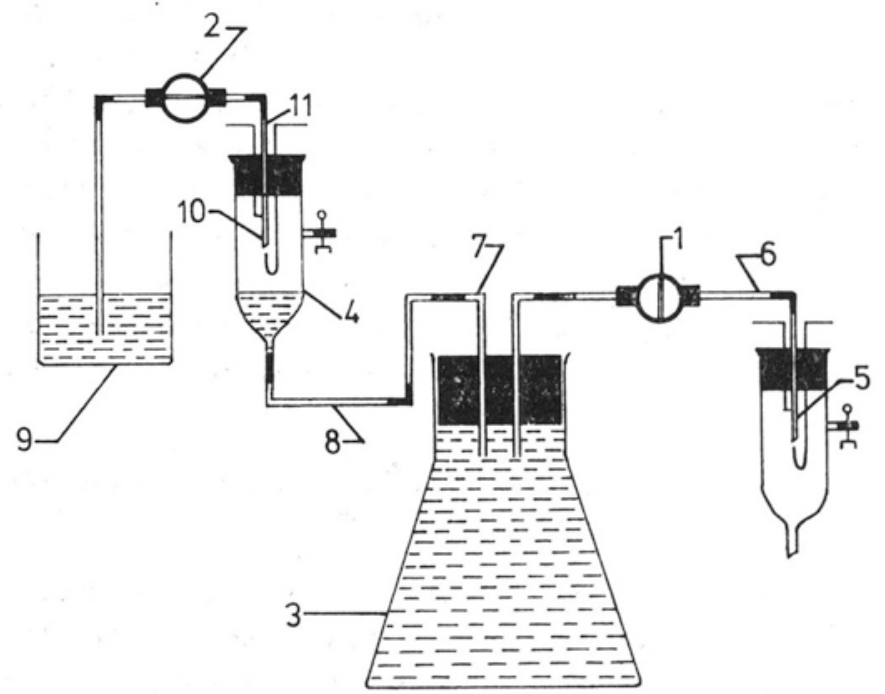

Fig. 3. Control apparatus. Operation of apparatus described in text

tube (6) connected at its outlet with injection needle (5). Vice versa, closing of cock (1) and opening of (2) makes possible recording of a volume change due to a fall of ambient temperature. Parallelly with the decrease of the volume of the fluid and the gas phase a pressure fall occurs in the system leading to outflow of drops from injection needle (10) connected by glass tube (11) with the open reservoir (9).

Recording of the outflowing water drops from both injection needles is done analogously as in the experimental system. The disadvantage of the here described control system is the necessity of earlier setting of cocks ( 1 and 2$)$ in a position making possible the correct reaction to temperature changes. Since temperature changes in light and darkness run in one direction the use of a control set-up is justified.

Table 3 gives as example the value of corrections resulting from temperature changes in light and in darkness, which should be introduced

\section{Table 3}

Calculation of weight of water taken up by plant, taking into account correction

\begin{tabular}{|c|c|c|c|c|}
\hline \multirow[t]{2}{*}{$\begin{array}{c}\text { Measurement } \\
\text { conditions }\end{array}$} & \multirow[t]{2}{*}{$\begin{array}{c}\text { Duration of } \\
\text { measurements } \\
\mathrm{h}\end{array}$} & \multicolumn{2}{|c|}{$\begin{array}{c}\text { Amount of water } \\
\text { recorded by system } \\
\mathrm{g}\end{array}$} & \multirow[t]{2}{*}{$\begin{array}{c}\text { Amount of water taken } \\
\text { up by plant } \\
\mathrm{g}\end{array}$} \\
\hline & & Control & Exp. & \\
\hline \multirow{2}{*}{ Light } & 1 & +0.176 & 0.673 & 0.849 \\
\hline & 15 & +0.341 & 22.147 & 22.488 \\
\hline \multirow{2}{*}{ Darkness } & 1 & -0.160 & 1.285 & 1.125 \\
\hline & 7 & -0.320 & 3.395 & 3.075 \\
\hline
\end{tabular}


into the readings from the experimental system. The highest correction is introduced in the first hour of measurement in light and in darkness. As the ambient temperature and that of the measuring systems tend to become equal, the value of the correction decreases. If the direction of pressure changes in the experimental system (due to water uptake by the plant) does not agree with the direction of pressure changes in the control system, the correction value should be added to the value from the experimental system. When the direction of pressure changes is the same in both systems, the correction value should be subtracted.

\section{APPARATUS FOR AND MEASUREMENT OF EXCRETION OF WEEPING SAP FROM A ROOT}

The measurement principle consists similarly in recording the particular sap drops flowing out of the injection needle under the influence of root pressure forces. For the measurement the same basic elements of the apparatus are applied which served for water uptake recording. A scheme of the set-up is given in Fig. 1b. In vessel (1) filled with water or nutrient solution the root to be examined is placed aerated with air introduced under pressure through glass tube (2). The cutting stem is connected with the sensing device (9) by a glass capillary (3) and a rubber connection (4 and 5). The sensor electrodes for root pressure measurement consist of two chrome-nickel wires in horizontal position at the same level under the injection needle. Recording of sap drops flowing out of the injection needle occurs similarly as that described in the case of water uptake measurement.

Calibration of system for 'measurement of outflow of weeping sap excreted by the root

The size of the sap drops recorded by the apparatus is determined by weight. The size can be regulated by the diameter of the injection needle. Table 1 shows the relation between the needle diameter and the size of the weeping sap drop.

\section{Experimental testing of method}

The experiments were made with tomato (Lycopersicon esculentum Mill. cv. Summerdown) plants. The growth conditions were the same as those applied for maize plants in water uptake measurements.

The performance of the apparatus was checked by measuring the rate of excretion of the weeping sap simultaneously on two plants aged 60 days. The measurements were carried out at constant temperature 
of $22^{\circ} \mathrm{C} \pm 1^{\circ}$ and under continuous weak dispersed light. The root system of plant A was placed in a vessel with tap water and that of plant B in nutrient medium.

The cyclicity in changes of sap excretion intensity described by Grossenbacher (1939) is illustrated in Fig. 4 by the sinus wave lasting over the 6 days of the experiment. The period of the more or less diurnal rhythm of sap excretion is protracted after $48 \mathrm{~h}$ and the range of the cycle gradually decreases.

In dependence on the water potential of the solution in which the root system was immersed, the amount of excreted sap differed. Root system A immersed in water excreted $104.408 \mathrm{~g}$ of sap in the course of 6 days, whereas the root placed in nutrient solution gave only $46.597 \mathrm{~g}$. The dynamics of changes in sap excretion by the roots is shown in Table 4. With time the amount of sap excreted by the roots decrease.

Table 4

Amount of sap excreted by tomato root system

\begin{tabular}{|c|c|c|c|c|c|c|c|}
\hline Solution & $\begin{array}{c}1 \mathrm{st} \\
24 \mathrm{~h}\end{array}$ & $\begin{array}{c}2 \mathrm{nd} \\
24 \mathrm{~h}\end{array}$ & $\begin{array}{c}3 \mathrm{rd} \\
24 \mathrm{~h}\end{array}$ & $\begin{array}{c}4 \text { th } \\
24 \mathrm{~h}\end{array}$ & $\begin{array}{c}5 \text { th } \\
24 \mathrm{~h}\end{array}$ & $\begin{array}{c}6 \text { th } \\
24 \mathrm{~h}\end{array}$ & $\begin{array}{c}\text { Total } \\
\text { a mount of } \\
\text { excreted sap }\end{array}$ \\
\hline $\begin{array}{c}\text { A } \\
\text { Tap water }\end{array}$ & 29.753 & 23.610 & 20.255 & 11.648 & 10.323 & 8.818 & 104.408 \\
\hline $\begin{array}{c}\text { B } \\
\begin{array}{l}\text { Nutrient } \\
\text { solution }\end{array}\end{array}$ & 19.136 & 11.591 & 6.373 & 4.032 & 2.781 & 2.318 & 46.597 \\
\hline
\end{tabular}

On the 6th day the quantity of sap excreted by a root immersed in water was 3 times less than that produced in the first $24 \mathrm{~h}$, and it was 8 times less from the root in nutrient medium.

Evaluation of the usefulness of the apparatus for water uptake and weeping sap excretion measurement

Water uptake and the rate of weeping sap excretion by the root were measured with the above described apparatus. The experiments performed lead to the following conclusions:

1. The basic elements of the apparatus (sensory device, supply system, recording system) can be used for:

(a) continuous recording of water uptake by a plant,

(b) continuous recording of weeping sap excreted by a root.

2. The described method of water uptake measurement should be applied in closed thermostated chambers. The control set-up allows the 

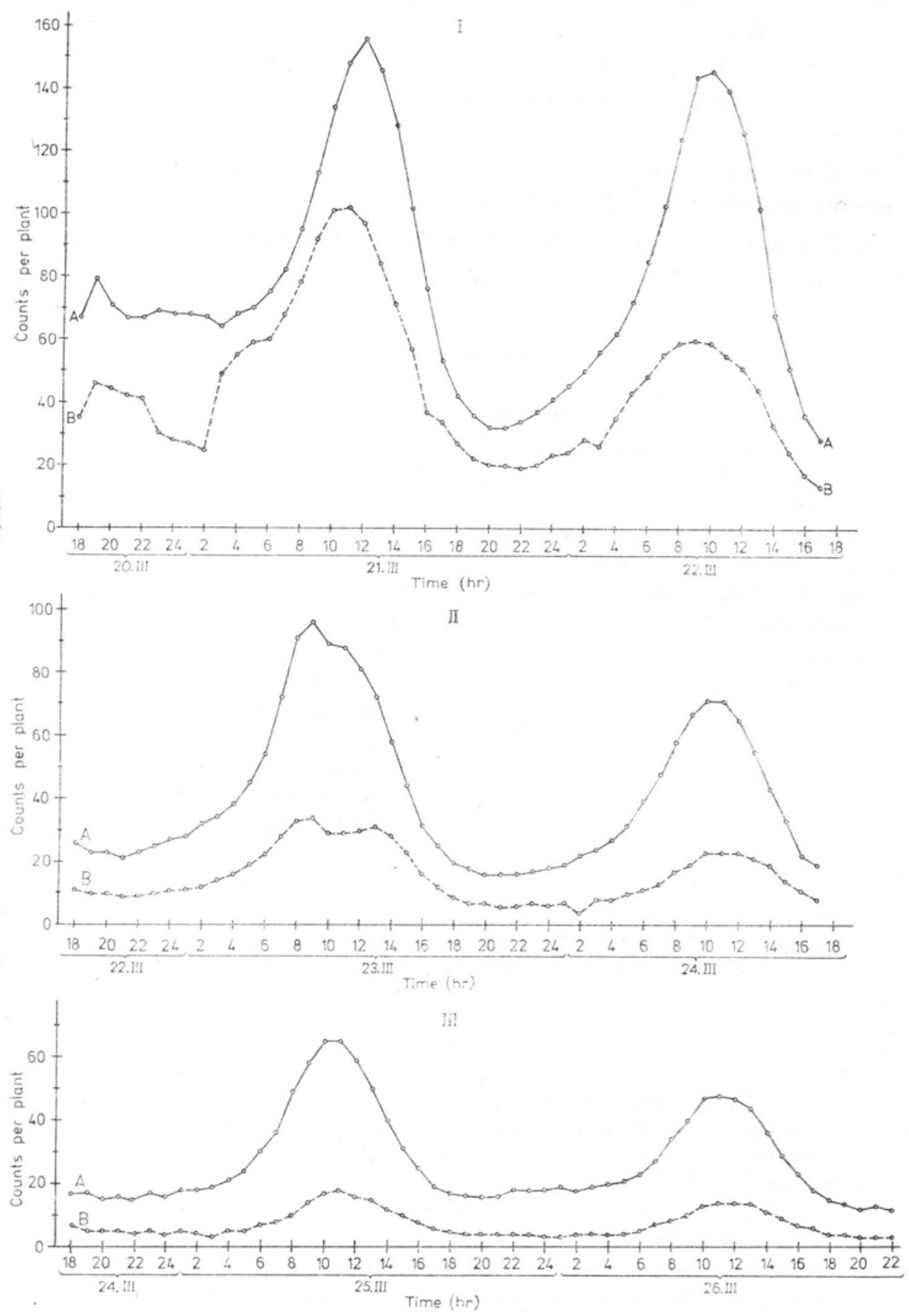

Fig. 4. Course of weeping sap excretion by tomato roots placed in tap water (A) and in nutrient medium (B) in the period March 20-26, 1975 
elimination of errors resulting from temperature variations due to change of light conditions.

3. The measurements can be performed on plants of various size, with any nutrient medium composition and at various rates of water uptake.

4. Root pressure can be studied under laboratory and natural conditions on herbaceous plants and trees.

5. The size of the taken up water portion or of excreted weeping sap recorded can be regulated by the diameter of the injection needle.

\title{
REFERENCES
}

Bentley M., 1959. Commercial Hydroponics. Bendon Books - Johannesburg. Czerski J., 1972. An easily operated apparatus to register the amount of the aqueous solution absorbed by a plant root system. Acta Soc. Bot. Pol. 41: $187-196$.

Grossenbacher K. A., 1939. Autonomic cycle of rate of exudation of plants. A. J. of Bot. 26: 107-109.

Slavik B., 1974. Methods of studying plant water relations. Publishing House of the Czechoslovak Academy of Sciences Prague.

\author{
Author's address: \\ Dr Jerzy Czerski \\ Institute of Botany, \\ Warsaw University, \\ Krakowskie Przedmieście 26/28 \\ 00-325 Warsaw; Poland
}

\author{
Automatyczny pomiar pobierania wody \\ i wydzielonego przez system korzeniowy soku płaczu
}

Streszczenie

Skonstruowano aparat umożliwiający przeprowadzenie automatycznego pomiaru dynamiki pobieranej wody przez roślinę. Podstawowe elementy aparatu mają również zastosowanie przy rejestracji natężenia wypływu soku płaczu w procesie parcia korzeniowego.

Zasada pomiaru polega na rejestracji wyciekających z igły iniekcyjnej kropel wody lub soku płaczu. Wypływ kropel wody jest uwarunkowany powstającym w układzie podciśnieniem, natomiast przy pomiarze parcia korzeniowego wypływ kropel soku spowodowany jest pawstającym nadciśnieniem. Wielkość rejestrowanej kropli wody lub soku płaczu może być regulowana.

Sprawdzono działanie aparatu mierząc w ciągu 24 godzin - na świetle i w ciemności - pobieranie wody przez kukurydzę. Wydzielanie soku płaczu rejestrowano na korzeniach pomidora $\mathrm{w}$ ciągu 6 dni. 